\title{
Obituary
}

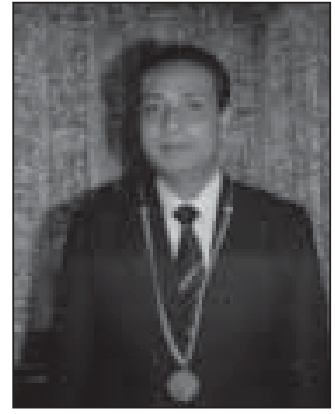

Dr. Amit C. Ganguli

1931-2005

\section{Glimpses of a Great Life}

Born 18-05-1931 at Dhaka (now Bangladesh) to Indu Prova and Dr. Adhir Chandra. His schooling was in Zilla (district) Govt. schools at Mymensingh, Rajshahi and Kushtia (Bangladesh) where his father, Dr. Adhir Chandra was posted as District Medical Superintendent of Jails. He had innumerable fascinating stories to tell of his very enjoyable and colorful childhood with a large family and friends, spent in the various provinces of the beautiful East Bengal (now Bangladesh).

He came over to Calcutta for ISC at Surendranath College. He did his MBBS from Calcutta National Medical (1949 - 1954), and M.S. from K.G.M.C., Lucknow (19591961).

His career as a plastic surgeon started in 1963 when he joined as a junior to Dr.M.M.Mukherjee at P.G. Hospital, Calcutta (now SSKM Hospital). Thus started the evolution of a career - essentially a process of acquiring skills by self- teaching. It was here that both of them developed the idea of lengthening of palate by "cheek flap", which he put into extensive clinical practice and later on, presented the paper at IPRS conf at Copenhagen, Denmark. "Palatal lengthening by cheekflap technique" Ganguli and Mukherjee, it finds mention in the 'bible' of cleft surgery- Cleft Craft by D. Ralph Millard.

Later, in 1974, he started the Plastic Surgery unit at Medical College Hospital, Calcutta and developed it into one of the finest super-speciality departments.
Tremendous volume of clinical work was performed in the area of cleft surgery, myo-cutaneous flaps, headneck surgery (esp. oral cancers and jaw tumors), incisional hernias etc. Academic activities and training (post graduate and junior plastic surgeons) went on simultaneously.

He was the President of APSI in 1983 and hosted a very memorable Annual Conference at the picturesque hillstation of Darjeeling. He was deeply involved and active in the affairs of our association, being a past president and member of the Board of Trustees.

He retired from Govt service in 1990 as Prof of Plastic Surgery and Head of Surgical Dept at Calcutta Medical College and thereafter continued with his private practice.

He was examiner for M.Ch.( Plastic Surgery) to many universities - Ahemdabad, Baroda, Lucknow, Madras, Benaras, Guwahati, as well as for the DNB exam.

He can be described as a brilliant teacher with fine surgical skills, as well as a large-hearted and benevolent man with an excellent sense of humour.

He was associated with various organizations to provide Free treatment to underprivileged cleft children:

- Lions Club, Jhargram (about 200 km from Cal.)

- Greenwood Hospitals, Aizwal (Mizoram)

- Prof Ajit Roy Foundation for cleft children (Calcutta)

A person of varied interests and hobbies - Reading was his passion, as was Photography, Angling and Music. His favourite authors were Nirad C Choudhury and John 
Grisham.

He was as good with the fishing rod, as with surgery! He enjoyed the music of K L Saigal and Pankaj Mullik. He was President of the Calcutta Rowing Club (one of the oldest rowing clubs of Asia) for 5 consecutive years and did a lot of research work on the history of rowing in India.

He would like nothing better than spending a quiet evening at home with a glass of the finest Scotch and watching a Hollywood classic. 'The Bridge on the River Kwai', Sholay, Roman holiday, were his all-time favourite movies, as were films of Satyajit Ray.
He is survived by his family- Aloka (wife), Arun, Arup and Arumoy (sons), daughters-in-law and grand children.

Prof. Ganguli Passed away on $23^{\text {rd }}$ June, 2005 after battling against prostate cancer for two long years. Perhaps he would have liked to end this obituary with these lines from Tagore:

"When I go from hence, let this be my parting word, that what I have seen is unsurpassable. I have tasted the hidden honey of this lotus that expands on the ocean of light, and thus am I blessed - let this be my parting word. and if the end comes here, let it come let this be my parting word....." 